\title{
Lexicographic Treatment of Negation in Sepedi Paper Dictionaries
}

\author{
D.J. Prinsloo, Department of African Languages, University of Pretoria, \\ Pretoria, South Africa (danie.prinsloo@up.ac.za)
}

\begin{abstract}
Negation in Sepedi is a complex matter - a variety of negative morphemes are used across complicated verbal and copulative structures and these morphemes are not interchangeable. Dictionary users in a text production situation need to be guided to the correct compilation of negative constructions. In most cases negative morphemes are not lemmatised in Sepedi paper dictionaries or if they are, the lexicographic treatment is inadequate. This paper provides an inventory of negation from which an abstraction of the negative morphemes is given. This is followed by a critical evaluation of Sepedi dictionaries and suggested model entries for lexicographic treatment of negative morphemes.
\end{abstract}

Keywords: NEGATION, SEPEDI, DICTIONARIES, LEXICOGRAPHY, SEPEDI VERBAL MOODS, SEPEDI COPULATIVES

Opsomming: Leksikografiese bewerking van negatiefvorming in Sepedi papierwoordeboeke. Negatiefvorming in Sepedi is kompleks - 'n verskeidenheid negatiewe morfeme word in ingewikkelde verbale en kopulatiewe strukture gebruik, en hierdie morfeme is nie uitruilbaar nie. Woordeboekgebruikers in 'n teksproduksiesituasie moet gelei word om negatiewe konstruksies korrek te kan saamstel. In die meeste gevalle word negatiewe morfeme nie in Sepedi-papierwoordeboeke gelemmatiseer nie, of is die leksikografiese behandeling daarvan onvoldoende. Hierdie artikel bevat ' $n$ inventaris van negatiefvorming waaruit ' $n$ abstraksie van die negatiewe morfeme gegee word. Dit word gevolg deur 'n kritiese evaluering van Sepedi woordeboeke en voorgestelde modelinskrywings vir leksikografiese behandeling van negatiewe morfeme.

Sleutelwoorde: NEGATIEFVORMING, SEPEDI, WOORDEBOEKE, LEKSIKOGRAFIE, SEPEDI WERKWOORD MODI, SEPEDI KOPULATIEWE

\section{Introduction}

For negation in isiZulu, Bosch and Faa $\beta$ (2018: 1) state that "as an important instrument of language use, one would therefore expect aspects of negation to be dealt with in dictionaries". They also emphasize that corpus studies reveal an "impressive number" of complex morphological constructions expressing negatives. The situation for Sepedi is no different. Corpus studies reveal that negative morphemes in Sepedi are frequently used. They are, however, often 
not lemmatised and treated in their own right in dictionaries. Prinsloo and Gouws (1996) attempted to reduce the negation strategies into a single socalled $\mathrm{g} a / \mathrm{sa} / \mathrm{se}$ convention. This convention has since been implemented in several dictionaries, e.g. Oxford Bilingual School Dictionary (ONSD) and Popular Northern Sotho Dictionary (POP). It is a powerful convention and reasonably user-friendly. The convention given in (1) caters for multiple negative constructions in the indicative, situative, relative, subjunctive, habitual, consecutive, infinitive and imperative moods and for the lemmatisation of verbs ending in $-e$. With a few exceptions verbs ending in $-e$ are not lemmatised in Sepedi dictionaries.

(1) rêke, rekê must buy; ..ga/sa/se.. not buy

What is required, however, for negative morphemes is that they should be separately lemmatised with full treatment. Traditional dictionaries reflect a strong word-bias, not focusing on items smaller than words such as morphemes, or multiword items, thus literally taking the alternative term for lemma, i.e. headword as the norm. This issue, however, falls beyond the scope of this article, cf. Gouws (1989) and Gouws and Prinsloo (2005) for a detailed discussion.

The aims of this article are to (a) give an overview of negation in Sepedi, presented as example driven rules, (b) extract the negation rules, (c) determine the frequency of use of negative morphemes in a Sepedi corpus, (d) critically evaluate the treatment of negation in Sepedi dictionaries and (e) compile model entries for Sepedi paper dictionaries. These model entries will firstly incorporate all the negative morphemes that have to be lemmatised and secondly, give a detailed scope of all the types of information and lexicographic conventions that have to be considered in the treatment of these lemmas.

\section{Overview of negation in Sepedi}

Negation is discussed in detail in Sepedi grammars such as Lombard, Van Wyk and Mokgokong (1985) and Poulos and Louwrens (1994) but is fragmented over different sections for the different verbal moods and copulatives. Inexperienced learners could find it difficult to get a full perspective on negation from grammar books. This article departs from such typical grammar-book descriptions but presents a summary of the full scope of negative constructions in only three tables. These tables will reflect an example-driven approach in a systematic way across different verbal moods and copulatives. The tables will also be used as a basis for the extraction of the negation rules, compilation of text boxes, running footers, back matter components, etc. in paper dictionaries. For the interested reader the full scope of verbal moods and copulatives is summarised in appendices $\mathrm{A}$ and $\mathrm{B}$. 


\section{Negation of verbal moods}

In this article the distinction of eight verbal moods for Sepedi by Lombard et al. (1985) is followed. The negation rules indicated in tables 1 to 3 are intended for a step-by-step build-up of the negative morphemes which will be regarded as lemma candidates. These negative morphemes will also be used in the evaluation of 12 Sepedi dictionaries. Tables 1 to 3, as well as appendices A and B, can also be used in the back matter of dictionaries as a reference address for the articles of negation morphemes in the central text. So, for example, references from the articles for $g a$, sa and se 'not' in the central text to the back matter contextualise $g a, s a$ and $s e$ in the broader perspective of verbs and copulatives and could be valuable for the user's cognitive needs.

Table 1: Negation strategies for verbal moods

\begin{tabular}{|c|c|c|c|}
\hline Mood & Negation strategy & Example & Neg. \\
\hline \multicolumn{4}{|l|}{3.1 Indicative } \\
\hline 3.1.1 Pres. & $g a+$ subject concord + verb stem ending -e & Ga ke reke 'I do not buy' & ga \\
\hline 3.1.2 Fut. & subject concord + ka se + verb stem ending -e & Nka se reke 'I shall not buy' & ka se \\
\hline 3.1.3 Past & $\begin{array}{l}\text { 1: } g a \text { se + alternative concord + verb stem } \\
\text { 2: } g a \text { se + subject concord + verb stem } \\
\text { ending -e } \\
\text { 3: } g a \text { + subject concord + a + verb stem } \\
\text { 4: } g a \text { + alternative concord + verb stem }\end{array}$ & $\begin{array}{l}\text { Ga se ka reka 'I did not buy' } \\
\text { Ga se ke reke 'I did not buy' } \\
\text { Ga ke a reka 'I did not buy' } \\
\text { Ga ka reka 'I did not buy' }\end{array}$ & $\begin{array}{l}\text { ga se } \\
\text { ga se } \\
\text { ga } \\
\text { ga }\end{array}$ \\
\hline \multicolumn{4}{|l|}{ 3.2 Situative } \\
\hline 3.2.1 Pres. & subject concord $+s a+$ verb stem ending -e & Ge ke sa reke 'If I do not buy' & sa \\
\hline 3.2.2 Fut. & subject concord + ka se + verb stem ending -e & Nka se reke 'I shall not buy' & ka se \\
\hline 3.2.3 Past & subject concord $+s a+$ verb stem & Ge ke sa reka 'If I did not buy' & sa \\
\hline \multicolumn{4}{|l|}{ 3.3 Relative } \\
\hline 3.3.1 Pres. & $\begin{array}{l}\text { subject concord }+s a+\text { verb stem ending }-\mathrm{e}+ \\
\text {-go/-ng }\end{array}$ & $\begin{array}{l}\text { Yo ke sa rekego 'I who do not } \\
\text { buy' }\end{array}$ & sa \\
\hline 3.3.2 Fut. & $\begin{array}{l}\text { subject concord + ka se + verb stem ending -e + } \\
\text {-go/-ng }\end{array}$ & $\begin{array}{l}\text { Yo nka se rekego 'I who shall } \\
\text { not buy' }\end{array}$ & ka se \\
\hline 3.3.3 Past & subject concord $+s a+$ verb stem +- go/-ng & $\begin{array}{l}\text { Yo ke sa rekago 'I who did not } \\
\text { buy' }\end{array}$ & sa \\
\hline 3.4 Subjunctive & subject concord $+s e+$ verb stem ending $-\mathrm{e}$ & $\begin{array}{l}\text { Gore ke se reke 'So that I do not } \\
\text { buy' }\end{array}$ & se \\
\hline 3.5 Habitual & subject concord $+s e+$ verb stem ending -e & $\begin{array}{l}\text { Ke se reke 'I (usually) do not } \\
\text { buy' }\end{array}$ & se \\
\hline 3.6 Consecutive & alternative concord $+s e+$ verb stem ending -e & Ka se reke 'I (then) did not buy' & se \\
\hline 3.7 Infinitive & go $+s e / s a+$ verb stem ending -e & Go se reke 'not to buy' & se/sa \\
\hline 3.8 Imperative & $\begin{array}{l}s e+\text { verb stem ending -e } \\
s e+\text { ke + alternative concord + verb stem }\end{array}$ & $\begin{array}{l}\text { Se reke! 'Do not buy!' } \\
\text { O se ke wa reka! 'Do not buy!' }\end{array}$ & se \\
\hline
\end{tabular}




\section{Negation of copulatives}

Louwrens (1994) gives a brief description of copulatives as follows:

A term used to refer to structures which incorporate a variety of prefixes (called particles in some grammatical descriptions of Northern Sotho) of which some resemble the subject concord (e.g. o bohlale, le bohlale, e bohlale, etc. 'he/it is clever'), whereas others have a unique form like ke (e.g. ke monna 'it is a man') and ga se (e.g. ga se monna 'it is not a man'), as well as a series of verb forms with the copulative verb stems -bê (e.g. ... gore a bê bohlale 'so that he may become clever'), -ba (e.g. ... a ba bohlale 'and then he became clever'), -le (e.g. ... gê a le bohlale 'if he is clever'), -se (e.g. ... gê a se bohlale 'if he is not clever') and -na (e.g. o na le lehufa 'she is jealous'). The copulative expresses the English verb to be, and is therefore translated with 'is', 'was', 'will be', 'has been', etc. (Louwrens 1994: 40)

The copulative in Sepedi is a very complex system - see appendix B for a detailed overview of the structure of static and dynamic copulatives. As for the verbal moods in table 1 the aim of the following section is to list the different negative copulative constructions and to extract the negative morphemes which will also be regarded as lemma candidates for Sepedi dictionaries.

\subsection{Static copulatives}

Louwrens (1991: 71) defines static as "referring to a state of rest which is characterised by the absence of motion or change". Three semantic relations are distinguished between a subject and a complement within the copulative, i.e. identification/equality, descriptive or associative.

Table 2: Negation strategies for static copulatives

\begin{tabular}{|c|c|c|c|}
\hline \multicolumn{4}{|c|}{ 4.1.1 Identifying } \\
\hline Mood & Negation strategy & Example & Neg. \\
\hline 4.1.1.1 Indicative & $\begin{array}{l}\text { ga + subject concord + com- } \\
\text { plement } \\
\text { ga } \text { se + complement }\end{array}$ & $\begin{array}{l}\text { Ga ke morutiši 'I am not a teacher' } \\
\text { Ga se morutiši 'It (he/she) is not a } \\
\text { teacher' }\end{array}$ & $\begin{array}{l}\text { ga } \\
\text { ga se }\end{array}$ \\
\hline 4.1.1.2 Situative & $\begin{array}{l}\text { subject concord + se + com- } \\
\text { plement }\end{array}$ & $\begin{array}{l}\text { Ge ke se morutiši 'If I am not a teacher' } \\
\text { Ge e se morutiši 'If it (he/she) is not a } \\
\text { teacher' }\end{array}$ & se \\
\hline 4.1.1.3 Relative & $\begin{array}{l}\text { subject concord + sego/seng } \\
+ \text { complement }\end{array}$ & $\begin{array}{l}\text { Yo ke sego morutiši 'I who am not a } \\
\text { teacher' } \\
\text { Yo e sego morutiši 'He/she who is not a } \\
\text { teacher' }\end{array}$ & se(go/ng) \\
\hline \multicolumn{4}{|c|}{ 4.1.2 Descriptive } \\
\hline 4.1.2.1 Indicative & $\begin{array}{l}\text { ga + subject concord + com- } \\
\text { plement }\end{array}$ & $\begin{array}{l}\text { Ga ke bohlale 'I am not clever' } \\
\text { Ga a bohlale 'He/she/they is not / are } \\
\text { not clever' }\end{array}$ & ga \\
\hline
\end{tabular}




\begin{tabular}{|c|c|c|c|}
\hline 4.1.2.2 Situative & $\begin{array}{l}\text { subject concord }+s e+\text { com- } \\
\text { plement }\end{array}$ & $\begin{array}{l}\text { Ge ke se bohlale 'If I am not clever' } \\
\text { Ge a se bohlale 'If he/she/they is / are } \\
\text { not clever' }\end{array}$ & se \\
\hline 4.1.2.3 Relative & $\begin{array}{l}\text { subject concord }+ \text { sego/seng }+ \\
\text { complement }\end{array}$ & $\begin{array}{l}\text { Yo ke sego bohlale 'I who am not clever' } \\
\text { Yo a sego bohlale 'He/she who is not } \\
\text { clever' }\end{array}$ & se \\
\hline \multicolumn{4}{|c|}{ 4.1.3 Associative } \\
\hline 4.1.3.1 Indicative & $\begin{array}{l}\text { ga + subject concord + na } \\
(\text { le })+\text { complement }\end{array}$ & $\begin{array}{l}\text { Monna ga a na (le) mpša 'The man does } \\
\text { not have (is not with) a dog' }\end{array}$ & ga \\
\hline 4.1.3.2 Situative & $\begin{array}{l}\text { subject concord }+s e+\text { na } \\
\text { (le) }+ \text { complement }\end{array}$ & $\begin{array}{l}\text { Ge monna a se na (le) mpša ' If the man } \\
\text { does not have (is not with) a dog' }\end{array}$ & se \\
\hline 4.1.3.3 Relative & $\begin{array}{l}\text { subject concord + se + nago/ } \\
\text { nang }(l e)+\text { complement }\end{array}$ & $\begin{array}{l}\text { Monna yo a se nago (le) mp̌sa 'The man } \\
\text { who does not have (is not with) a dog' }\end{array}$ & se \\
\hline
\end{tabular}

\subsection{Dynamic copulatives}

Louwrens (1991: 71) defines dynamic as "referring to a state in which things are in motion and therefore changing". Dynamic copulative constructions are therefore often translated as '(to) become'. Similar to static copulatives, dynamic copulatives distinguish identifying, descriptive and associative relations between the subject and complement.

\subsubsection{Identifying dynamic copulatives}

As in the case of identifying static copulatives in table 2, first and second persons use their own subject concords, i.e. $k e, r e, o$ and $l e$ but third persons use a neutral subject concord $e$. In table 3 only examples with third person class 1 monna 'man' as subject will be given.

Table 3: Negation strategies for dynamic copulatives

\begin{tabular}{|c|c|c|c|}
\hline \multicolumn{4}{|c|}{ 4.2 1 Identifying } \\
\hline Mood & Negation strategy & Example & Neg. \\
\hline \multicolumn{4}{|c|}{ 4.2.1.1 Indicative } \\
\hline 4.2.1.1.1 Pres. & $\begin{array}{l}\text { ga }+ \text { neutral subject concord }+ \text { be }+ \\
\text { complement }\end{array}$ & $\begin{array}{l}\text { Monna ga e be morutiši 'The man } \\
\text { does not become a teacher' }\end{array}$ & ga \\
\hline 4.2.1.1.2 Fut. & $\begin{array}{l}\text { Neutral subject concord + ka se + be + } \\
\text { complement }\end{array}$ & $\begin{array}{l}\text { Monna e ka se be morutiši 'The } \\
\text { man will not become a teacher' }\end{array}$ & ka se \\
\hline 4.2.1.1.3 Past & $\begin{array}{l}\text { 1. ga se+ neutral subject concord + } \\
\text { ba + complement } \\
2: \text { ga se + neutral subject concord + } \\
\text { be + complement } \\
3: g a+\text { subject concord + a + verb } \\
\text { stem } \\
4: g a+\text { alternative concord + ba + } \\
\text { complement }\end{array}$ & $\begin{array}{l}\text { Monna ga se ya ba morutiši } \\
\text { Monna ga se e be morutiši } \\
\text { Monna ga e a ba morutiši } \\
\text { Monna ga ya ba morutiši } \\
\text { 'The man did not become a } \\
\text { teacher' }\end{array}$ & $\begin{array}{l}\text { ga se } \\
\text { ga se } \\
\text { ga } \\
\text { ga }\end{array}$ \\
\hline
\end{tabular}




\begin{tabular}{|c|c|c|c|}
\hline \multicolumn{4}{|l|}{ 4.2.1.2 Situative } \\
\hline 4.2.1.2.1 Pres. & $\begin{array}{l}\text { Neutral subject concord }+s a+b e+ \\
\text { complement }\end{array}$ & $\begin{array}{l}\text { Ge monna e sa be morutiši 'If the } \\
\text { man does not become a teacher' }\end{array}$ & sa \\
\hline 4.2.1.2.2 Fut. & $\begin{array}{l}\text { Neutral subject concord }+k a \text { se }+ \text { be }+ \\
\text { complement }\end{array}$ & $\begin{array}{l}\text { Ge monna e ka se be morutiši 'If } \\
\text { the man will not become a } \\
\text { teacher' }\end{array}$ & ka se \\
\hline 4.2.1.2.3 Past & $\begin{array}{l}\text { Neutral subject concord }+s a+b a+ \\
\text { complement }\end{array}$ & $\begin{array}{l}\text { Ge monna e sa ba morutiši 'If the } \\
\text { man did not become a teacher' }\end{array}$ & sa \\
\hline \multicolumn{4}{|l|}{ 4.2.1.3 Relative } \\
\hline 4.2.1.3.1 Pres. & $\begin{array}{l}\text { Neutral subject concord }+s a+\text { be- } \\
\text { go/ng + complement }\end{array}$ & $\begin{array}{l}\text { Monna yo e sa bego morutiši 'The } \\
\text { man who does not become a } \\
\text { teacher' }\end{array}$ & sa \\
\hline 4.2.1.3.2 Fut. & $\begin{array}{l}\text { Neutral subject concord + ka se+be- } \\
\text { go/ng + complement }\end{array}$ & $\begin{array}{l}\text { Monna yo e ka se bego morutiši } \\
\text { 'The man who does not become a } \\
\text { teacher' }\end{array}$ & ka se \\
\hline 4.2.1.3.3 Past & $\begin{array}{l}\text { Neutral subject concord }+s a+\text { ba- } \\
\text { go/ng }+ \text { complement }\end{array}$ & $\begin{array}{l}\text { Monna yo e sa bago morutiši 'The } \\
\text { man who did not become a } \\
\text { teacher' }\end{array}$ & sa \\
\hline 4.2.1.4 Subjunctive & $\begin{array}{l}\text { Neutral subject concord }+s e+\text { be }+ \\
\text { complement }\end{array}$ & $\begin{array}{l}\text { Gore monna e se be morutiši 'So } \\
\text { that the man does not become a } \\
\text { teacher' }\end{array}$ & se \\
\hline 4.2.1.5 Habitual & $\begin{array}{l}\text { Neutral subject concord }+s e+\text { be }+ \\
\text { complement }\end{array}$ & $\begin{array}{l}\text { Monna e se be morutiši 'Usually } \\
\text { the man does not become a } \\
\text { teacher' }\end{array}$ & se \\
\hline 4.1.2.6 Consecutive & $\begin{array}{l}\text { Neutral alternative concord }+s e+\text { be }+ \\
\text { complement }\end{array}$ & $\begin{array}{l}\text { Monna ya se be morutiši 'The } \\
\text { man (then) did not become a } \\
\text { teacher' }\end{array}$ & se \\
\hline 4.2.1.7 Infinitive & go $+s e / s a+$ be + complement & $\begin{array}{l}\text { Go se be morutiši 'Not to become } \\
\text { a teacher' }\end{array}$ & $\begin{array}{l}\text { se } \\
\text { sa }\end{array}$ \\
\hline 4.2.1.8 Imperative & $\begin{array}{l}s e+\text { be }+ \text { complement } \\
s e+\text { ke + alternative concord }+ \text { ba }+ \\
\text { complement }\end{array}$ & $\begin{array}{l}\text { Se be morutiši! 'Do not become a } \\
\text { teacher!' } \\
\text { O se ke wa ba morutiši! 'Do not } \\
\text { become a teacher!' }\end{array}$ & se \\
\hline
\end{tabular}

\subsubsection{Descriptive dynamic copulatives}

Descriptive dynamic copulatives use the same negation strategies as the descriptive identifying copulatives, cf. table 3 but all persons and classes use their own subject concords e.g. Monna ga e be morutiši 'the man does not become a teacher (4.2.1.1, table 3) becomes Monna ga a be bohlale 'the man does not become clever' and will not be presented here as a separate full table for the different moods.

\subsubsection{Associative dynamic copulatives}

Associative dynamic copulatives use the copulative verb stem $b a$ instead of $n a$ which is used in the associative static copulatives (cf. 4.1.3, table 2). Associative dynamic copulatives occur in all of the moods and follow the same negation 
rules as ordinary verbs as in table 1 . Associative dynamic copulatives also use the same negation strategies as associative static copulatives except for the situative and relative where the negation morpheme $-s a$ is used in associative dynamic copulatives, e.g. a sa be le 'not be with' instead of -se (4.1.3.2, table 2) for static associative copulatives.

Due to space limitations the associative dynamic copulatives will also not be presented here as a separate full table for the different moods.

The reference numbers given in the first columns of tables 1 to 3 for the suggested lemma candidates $g a, s a$, se(go/ng), ga se and $k a$ se in the final columns of these tables, are intended to guide the lexicographer in the microstructural treatment of these lemmas. The lexicographer should, namely, try to include examples representing the moods, morphological changes in subject concords, verbal endings, grammatical structures, etc. in following the reference numbers for each negation morpheme. See discussion below on the suggested scope for treatment and utilization of the reference numbers.

\section{Frequency of use of negative morphemes in a Sepedi corpus}

Negative morphemes are frequently used in Sepedi. Consider the following approximate counts for $g a, s a, s e, g a$ se and $k a$ se in a corpus of 1.2 million tokens in table $4 .^{1}$

Table 4: Frequency counts for negative morphemes in Sepedi

\begin{tabular}{|l|l|}
\hline Morpheme & Occurrences \\
\hline ga & 5,000 \\
\hline sa & 3,000 \\
\hline se & 5,000 \\
\hline ga se & 300 \\
\hline ka se & 1,800 \\
\hline
\end{tabular}

\section{A critical evaluation of the treatment of negation in Sepedi diction- aries}

Twelve Sepedi dictionaries were studied for their lemmatisation and treatment of the negative morphemes $g a, s a, s e, g a$ se and $k a$ se and will be briefly evaluated in this section. The dictionaries consulted were Comprehensive Northern Sotho Dictionary (henceforth referred to as GNSW), Kort Drietalige Sakwoordeboek (KDS), Noord-Sotho-Afrikaans woordelys (NAAN), New English-Northern Sotho Dictionary (NEN), Oxford Bilingual School Dictionary (ONSD), Popular Northern Sotho Dictionary (POP), Pukuntšutlhaloši ya Sesotho sa Leboa (PTLH), Pukuntšu Dictionary (PUKU), Pukuntšu woordeboek (PUKU'89), Sediba (SEDIBA), Sesotho sa Leboa- 
English Pukuntšu Dictionary (SEPD) and Woordeboek Afrikaans-Noord-Sotho (WANS). Full references are given in the bibliography.

First, consider table 5 for ten dictionaries where Sepedi is the target language in English-Sepedi or, Afrikaans-Sepedi dictionaries.

Table 5: Dictionary articles for not / nie

\begin{tabular}{|c|c|}
\hline PUKU'89 & No entry \\
\hline NEN & not, adv. se, ga, ga se \\
\hline POP & not se, ga, ga se \\
\hline ONSD & 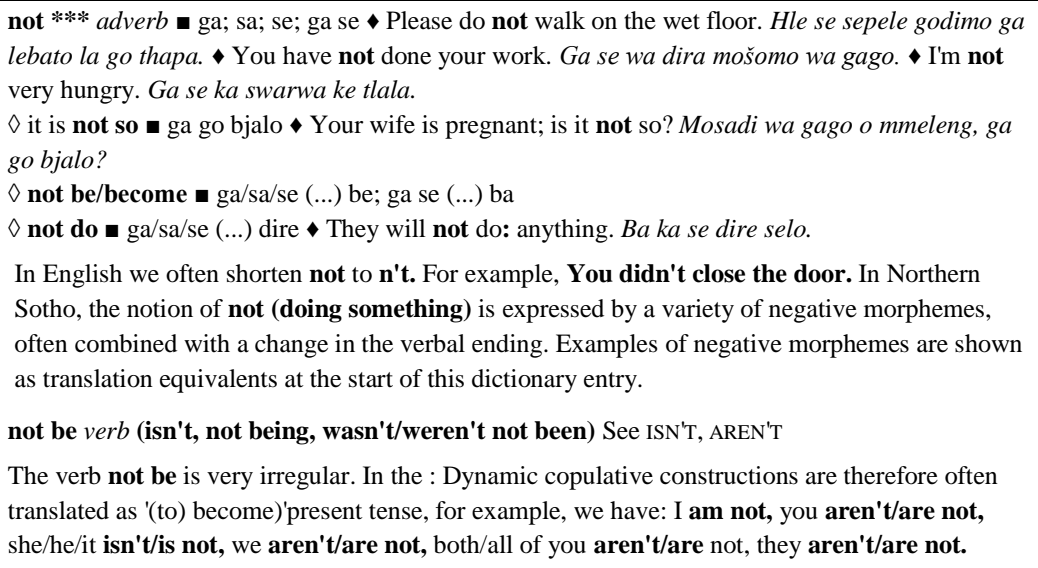 \\
\hline SEPD & not $n e g$ ga; e sego \\
\hline WANS & nie ga-, se-, ga se- \\
\hline NAAN & nie, ga. \\
\hline PUKU & nie ga, sa, se, ga se. \\
\hline KDS & nie e sego not \\
\hline SEDIBA & $\begin{array}{l}\text { not ga, sa, se I do - run ga ke kitime he/she/it/they is/are - ga se I did - eat ga se ka ja he is - clever } \\
\text { ga a bohlale I do - know ga ke tsebe [ne] (while) he is - falling a sa we do - go home se yê gae do - } \\
\text { come (you, s:) ankê o se tlê the water should - boil whatsoever mêêtse a se kê a bela no longer se sa } \\
\text { not at all ke/kê (a.v.) you should - start fearing o se kê wa thôma go fšêga they are not overcome } \\
\text { at all ga ba ke ba šitwa you (pl.) must not damage it at all le se keng la di senya } \\
\text { not, } b \text { - - se while we are not far away re - kgolê he/she was not e bê e - }\end{array}$ \\
\hline
\end{tabular}

PUKU'89 did not lemmatise not, NAAN only lists $g a$ as a translation equivalent. NEN, SEPD and POP simply give the translation equivalents of not as se(go), ga and $g a$ se, thus missing out on $s a$. PUKU gives the translation equivalents $g a$, sa, se and $g a$ se. None of the dictionaries with the exception of ONSD and SEDIBA gives information on grammar, pronunciation, examples of use, indicate circumflexes or tone. ONSD and SEDIBA do much better by giving a more exhaustive treatment including translated examples. ONSD also provides frequency and part of speech information as well as additional information in text boxes. 
In tables 6 to 8, author inserted English translations for Afrikaans are given in double square brackets.

Table 6: Dictionary articles for ga

\begin{tabular}{|c|c|}
\hline PUKU'89 & ga ontk. -morf., ind. L: nie. [[negative morpheme indicative L (tone) not)]] \\
\hline NEN & ga, neg. part., not, not to; -ke rate, I do not want. \\
\hline POP & ga not: ga ke morutiši I am not a teacher; at: ga Madika at Madika's place; if, when \\
\hline ONSD & 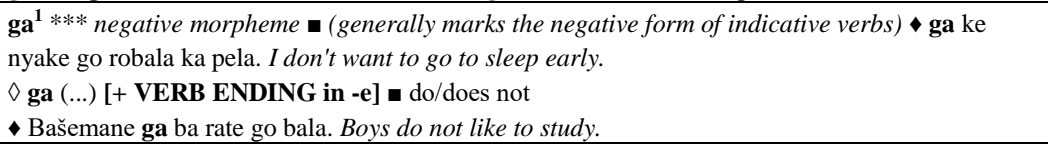 \\
\hline SEPD & $\mathbf{g a}^{1}$ neg. the negative morpheme; not; place of; if; when \\
\hline NAAN & ga (negatiewe bywoord), nie. [[(negative adverb) not]] \\
\hline PUKU & $\begin{array}{l}\text { ga, van, na, nie, as, by [[of, to, not, if, at]]; - e sa le, dit is nie meer [[it is no more]]; - se ka, (daar } \\
\text { is) baie [[there is plenty]]. }\end{array}$ \\
\hline SEDIBA & $\begin{array}{l}\text { ga nie not - } \text { ke kitime } \text { ek hardloop nie I don't run - se hy/sy/dit/hulle is nie he she/it/they is/are not } \\
\text { - se } k \text { a ja } \mathrm{ek} \text { het nie geëet nie I did not eat } \\
\text { - a bohlale hy is nie slim nie he is not clever }\end{array}$ \\
\hline PTLH & No entry \\
\hline GNSW & $\begin{array}{l}\text { GA (ga-) [ontkennende vormelement] // [negative formative] ga re bône ons sien nie // we don't } \\
\text { see }\end{array}$ \\
\hline
\end{tabular}

There is no entry for $g a$ in PTLH but entries are given in the other nine dictionaries. SEPD has an entry for $g a$ but does not lemmatise the possessive, place of and situative particle if, when as separate entries. This runs against the lemmatisation policy followed in this dictionary i.e. to separate such homonyms and to allocate homonym numbers. POP also treats the negative morpheme $g a$ and the locative $g a$ as well as if, when in the same entry. This is also the case in PUKU where nie [not] is given amidst four other unrelated translations. At least one of the examples given illustrates the use of $g a$ in an identifying copulative containing the progressive $s a$. The second example ga se $k a$, '(daar is) baie' [there is plenty], however, makes no sense for any of the other related meanings, i.e. of, to, if, by given. NEN treats $g a$ 'not' in a separate entry and gives an example. No examples are given in SEPD, NAAN and PUKU'89 and therefore are not of much help for text production.

The entries for $g a$ in SEDIBA and especially ONSD are much more informative. SEDIBA does well in covering four different negative constructions in the example sentences given, i.e. negation in the indicative present (3.1.1, table 1), indicative identifying copulative (4.1.1.1, table 2), indicative past tense (3.1.3(1), table 1) and indicative descriptive copulative respectively. The examples also indicate two other important aspects, i.e. the use of subject concords of the first person as well as class 1 and that the past tense form of the verb changes back to the present tense. They also illustrate that unlike English, for example, Sepedi does not distinguish between he is, she is, they are, and it is - they all convert to $k e$ 'it is' and ga se 'it is not' in the negative. SEDIBA also gives exam- 
ples of ga se for both verbs and copulatives. PUKU'89 indicates tone by means of the letters L 'low' and H 'high'. GNSW also indicates tone e.g. high tones é and $o ́$ - low tones are unmarked. ONSD's entry for $g a$ is of high lexicographic quality. It gives detailed grammatical guidance stating that $g a$ is a morpheme, used in the negative of the indicative and that the verbal ending changes to $-e$ illustrated by examples. It also gives frequency information by means of a one, two or three star convention - indicating in this case that $g a$ is one of the top most frequently used tokens in a Sepedi corpus, cf. table 4.

Table 7: Dictionary articles for sa

\begin{tabular}{|c|c|}
\hline PUKU'89 & $\begin{array}{l}\mathbf{s a}^{\mathbf{4}} \text {, neg. morf. sit./rel. L; gê o sa boe, as jy nie terugkeer nie [[if you do not return]]; gê o sa boa, } \\
\quad \text { as jy nie teruggekeer het nie. [[if you did not return]] }\end{array}$ \\
\hline NEN & sa, adv., still, yet, ke — ja, I am still eating;[;] — with the negative, no longer, not; —ntše, still. \\
\hline POP & $\begin{array}{l}\text { sa of, belonging to: selêpê sa ka my axe; not: gê ba sa boe if they do not return; still, yet: ba sa } \\
\text { ithuta they are still studying; he/she/it then: sa fihla it then arrived; clear, dawn; disappear }\end{array}$ \\
\hline ONSD & $\begin{array}{l}\mathbf{s a}^{\mathbf{4}} \text { *** negative morpheme (marks the negative form of situative verbs) } \\
\text { se ba thuše gape. If they don't pay me, I won't help them again. }\end{array}$ \\
\hline SEPD & No entry \\
\hline NAAN & No entry \\
\hline PUKU & $\begin{array}{l}\text { sa, steeds, nog; - saam met die negatief nie meer nie; ga a - rate, hy wil nie meer nie; ge a - rate, } \\
\text { as hy nie wil nie; - le, terwyl. }\end{array}$ \\
\hline SEDIBA & sa nie not a - we (terwyl) hy nie val nie (while) he is not falling \\
\hline PTLH & No entry \\
\hline GNSW & $\begin{array}{l}\text { SA (sa-) [ontkennende vormelement in infinitiewe en partisipiale wyses] // [negative formative in } \\
\text { infinitive and participial moods]; go sa bône om nie te sien nie // not to see; re sa bône (terwyl) } \\
\text { ons nie sien nie // we not seeing }\end{array}$ \\
\hline
\end{tabular}

In table 7 no entries were given for $s a$ in SEPD, NAAN and PTLH. NEN and PUKU treat the negative morpheme sa within the article of still. If the user reads through all four entries given for $s a$, (s)he will eventually find the information given for the use of $s a$ in negative constructions but the possibility of missing the information on negation is high. POP does even worse by treating the possessive, negative, subject concord and progressive in a single entry for $s a$. GNSW does well in stating that $s a$ is used in negation of the infinitive and situative moods, illustrated by examples. SEDIBA gives the relevant basic information with an example from the situative. ONSD does well in providing a homonym number, frequency indication, part of speech as well as morphological information and a translated example in a relatively short entry. PUKU'89 is the only dictionary indicating negation with $s a$ in the relative mood. 
Table 8: Dictionary articles for se

\begin{tabular}{|c|c|}
\hline PUKU'89 & $\begin{array}{l}\mathbf{s e}^{\mathbf{4}} \text {, neg. morf. L; [[negative morpheme L (low tone)]] go se bônê, om nie te sien nie. [[not to } \\
\text { see]] }\end{array}$ \\
\hline NEN & No entry \\
\hline POP & se it/he/she; not \\
\hline ONSD & $\begin{array}{l}\mathbf{s e}^{\mathbf{4}} * * * \text { copulative verb } \mathbf{\square} \text { is/are/am not } \bullet \mathrm{O} \text { lebile kae ge e se go Tshikidi? Where are you off to, } \\
\text { if not to Tshikidi? } \\
\mathbf{s e}^{\mathbf{5} * * *} \text { negative morpheme } \mathbf{m a r k s} \text { the negative form of subjunctive, imperative and } \\
\text { consecutive verbs) Hlokomela gore o se forwe ke morekiši. Watch out that you are not } \\
\text { cheated by the trader. } \\
\ldots \\
\mathbf{s e g o} \\
\text { gago e sego a ka. Those are your words, which are not mine. }\end{array}$ \\
\hline SEPD & No entry \\
\hline NAAN & No entry \\
\hline PUKU & $\begin{array}{l}\text { se, (neg.form.), nie; se, onderwerp -, voorwerpskakel v/d. se klas; se sa, nie meer nie. [[subject - } \\
\text { object concord of the se class, no more]] }\end{array}$ \\
\hline SEDIBA & 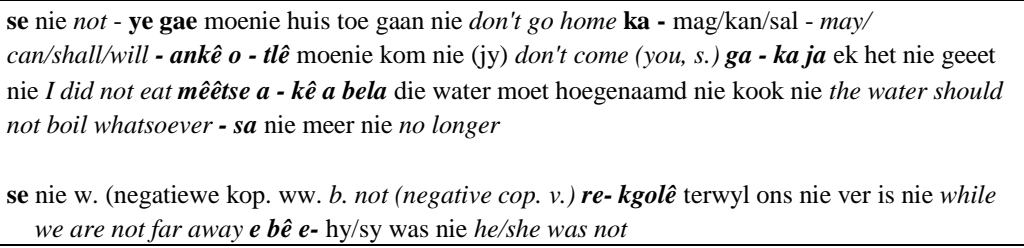 \\
\hline PTLH & No entry \\
\hline GNSW & $\begin{array}{l}\text { SE (se-) [ontkenningsvormelement] // [neg. formative] nie // not; gore re } \sim \text { rutê sodat ons nie } \\
\text { onderrig nie // so that we should not teach; re ka } \sim \text { rutê ons sal nie/kan nie onderrig nie // we } \\
\text { shall not/cannot teach; re } \sim \text { sa ruta terwyl ons nie meer onderrig nie // while we no longer teach; } \\
\text { ga } \sim \text { ra ruta ons het nie onderrig nie // we did not teach; re } \sim \text { rute ons onderrig nie gedurig nie // } \\
\text { we do not teach habitually. } \\
\text { SE (-se) (d.v.) nié // not; re } \sim \text { ra ka ra ruta terwyl ons nie onderrig het nie // while we did not } \\
\text { [t] each }\end{array}$ \\
\hline
\end{tabular}

In table 8 no entries were given for se in SEPD, NEN, NAAN and PTLH. POP gives a translation equivalent following translation equivalents of $s e$ as a concord. PUKU treats the negative together with subject and object concords but the information on negation of the progressive is valuable. The entries given in ONSD, SEDIBA and GNSW are much more informative giving a variety of information types such as frequency, part of speech, multiple examples, negation in a number of different constructions, etc. They contain most of the elements required for a model entry for se in paper dictionaries, cf. discussion below. As far as se ke (3.8, table 1 and 4.2.1.8, table 3 ) is concerned, Lombard et al. (1985: 188) regard ke as an auxiliary verb stem. From a user perspective se ke should be lemmatised and treated or at least be treated in the articles of se and ke. SEPD has an entry for se ke with translation equivalents do not, don't. GNSW treats se ke in the article of ke with reference to its seventh lemma for $k a$. POP 
has an entry for se ke with translation equivalent must not but under the lemma seke.

Table 9: Dictionary articles for ga se

\begin{tabular}{|c|c|}
\hline PUKU'89 & No entry \\
\hline NEN & No entry \\
\hline POP & No entry \\
\hline ONSD & 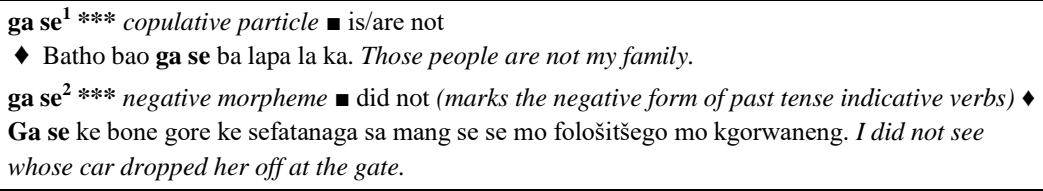 \\
\hline SEPD & No entry \\
\hline NAAN & No entry \\
\hline PUKU & No entry \\
\hline SEDIBA & No entry \\
\hline PTLH & No entry \\
\hline GNSW & No entry \\
\hline
\end{tabular}

SEDIBA gives an example of $g a$ se (313(1)(2), 4.1.1, 4.2.1.1.3(1)(2)) in the negative of the past tense in the article of se in table 8 but only ONSD presents it as lemmas with full treatment.

$\mathrm{Ka}$ se (3.1.2, 3.2.2, 3.3.2, table 1) is not lemmatised in any of the dictionaries but ONSD gives $k a$ se as part of an example for $s a$ in table 7. A model entry for $k a$ se will be suggested in the next paragraph.

\section{The compilation of model entries for paper Sepedi dictionaries for the extracted negative morphemes}

In the final columns of tables 1 to 3 above the negative morphemes $g a$, sa, se(go/ng), ga se and ka se were extracted from the negation rules for verbal moods and copulatives. These morphemes are proposed as required lemmas in the macrostructure in Sepedi dictionaries. It will also be attempted to formulate the required essential scope of information types and lexicographic conventions to be considered by the lexicographer in their microstructural treatment in terms of grammatical and semantic information. The lexicographer must strive to cover the full scope of use of a specific negation morpheme in the lexicographic treatment. So, for example, should ga se not only be lemmatised but the compiler should also cover its use in verbal moods as past tense negative (3.1.3(1)(2), table 1) and as negative copulative (4.1.1.1, table 2). Such guidance is essential for especially text production with copulatives. No formal user studies of negation has as yet been done for Sepedi but a common error observed in tests of undergraduate students is incorrect negation in the indica- 
tive of the static, identifying copulative (4.2.1.1.1, table 2). Learners would for example correctly construct the copulative I am not a teacher as ga ke morutiši but incorrectly apply negation with ga to the man is not a teacher as *monna ga o morutiši or even *monna ga ke morutiši instead of monna ga se morutiši. From the 10 dictionaries consulted for their treatment of $g a$ in table 6, only ONSD provides the required guidance by lemmatising and treating $g a s^{1}$.

Lexicographers should firstly decide on the generic scope of information types to be presented, i.e. which data types should be considered in all cases. They should then decide on the conventions, structural markers and layout strategies to be used consistently. Consider the following recommended information types for negative morphemes in Sepedi:

- Homonym differentiation, preferably by homonym numbers presented as superscripts, cf. ONSD, SEPD, PUKU'89 in tables 6 to 9.

- Frequency information by means of a specific convention such as stars or filled/unfilled diamonds, cf. ONSD in tables 6 to 9 .

- Part of speech.

- Translated examples.

- Pronunciation guidance.

- Grammatical and text production guidance, cf. ONSD in tables 6 to 9.

- Tonal indication low / high, cf. PUKU'89 in tables 6 to 8.

- Indication of circumflexes, cf. SEDIBA, GNSW and POP.

- Text boxes.

- Front and back matter.

- Cross references to internal and external sources.

- Running footers.

Consider also the following recommendations for dictionary conventions and structural markers:

- Lemma in boldface.

- Translation equivalents in Roman.

- Source language examples in boldface and italics.

- Translations of examples in italics.

- Use of indicators such as blocks and diamonds to separate data types, cf. ONSD.

- Hard carriage returns, i.e. information on a new line, cf. ONSD in table 6.

Note, however, that there are no binding rules for conventions and structural markers but the lexicographer will be well-advised to follow the practices that users became used to in other dictionaries such as presenting the lemma in lowercase and in boldface, translation equivalents in Roman, etc.

The suggested scopes and model entries for each of the negative morphemes $g a$, sa, se, ga se, and ka se are briefly presented in the following paragraphs. 
For $g a$ the scope includes the indicative present (3.1.1) and past (3.1.3(3)(4)) for verbs and all copulatives in the indicative of identifying (4.1.1.1), descriptive (4.1.2.1) and associative (4.1.3.1), static copulatives and the indicative of dynamic copulatives (4.2.1.1.1), (4.2.1.1.3(3)(4)). ONSD's entry in (2) gives good treatment for $g a$ in respect of the negative of the indicative present (3.1.1).

(2)

$\mathbf{g a}^{1}{ }^{* * *}$ negative morpheme (generally marks the negative form of indicative verbs)

- ga ke nyake go robala ka pela. I don't want to go to sleep early.

$\diamond$ ga (...) [+ VERB ENDING in -e] a do/does not

- Bašemane ga ba rate go bala. Boys do not like to study.

A reference to the lemmas $g a s e^{1}$ and $g a s e^{2}$ is advisable so that the user will not miss the treatment of the indicative past for verbs (3.1.3(3)(4), table 1) and the copulatives (4.1.1.1, table 2 and 4.2.1.1.3.(1)(2), table 3). This entry could be further enhanced by an example from class 1 to indicate that the subject concord changes from an $o$ in the positive to $a$ in the negative. Indication of circumflexes as in POP and PUKU is also recommended.

For $s a$ the scope includes situative present (3.2.1), past (3.2.3), relative present (3.3.1), and past (3.3.3) in table 1 for verbs and all dynamic copulatives in the situative (4.2.1.2.1), (4.2.1.2.3) and relative (4.2.1.3.1), (4.2.1.3.3) in table 3.

PUKU'89 provides a good entry for $s a$ given in (3).

(3)

$\mathbf{s a}^{4}$, neg. morf. sit./rel. L; gê o sa boe, as jy nie terugkeer nie [[if you do not return]]; gê o sa boa, as jy nie teruggekeer het nie. [[if you did not return]]

The different $s a$-morphemes are separated and lemmatised with superscript homonym numbers. It was the only entry found indicating that $s a$ is used as negation morpheme for both the situative and relative moods, illustrated by translated examples from present and past tense forms of the situative and indicating tone. The entry can be improved by adding frequency information, treatment and examples in respect of the past tense negatives (3.2.3 and 3.3.3, table 1) and dynamic copulatives (4.2.1.2.1, 4.2.1.2.3, 4.2.1.3.1 and 4.2.1.3.3) in table 3. Indication of circumflexes, cf. POP and PUKU, as well as tone on the vowels themselves is also recommended.

For se the scope includes consideration of the subjunctive (3.4), habitual (3.5), consecutive (3.6), infinitive (3.7) and imperative (3.8) for verbs (table 1); for static copulatives: identifying, situative (4.1.1.2), relative (4.1.1.3), descriptive, situative (4.1.2.2), relative (4.1.2.3), associative, situative (4.1.3.2), relative (4.1.3.3) (table 2) and for dynamic copulatives situative (4.2.1.2.1), (4.2.1.2.3) and relative (4.2.1.3.1), (4.2.1.3.3) in table 3.

SEDIBA provides good entries for se given in (4): 
(4)

se nie not - ye gae moenie huis toe gaan nie don't go home $\mathbf{k a}$ - mag/kan/sal - may/ can/shall/will - ankê o - tlê moenie kom nie (jy) don't come (you, s.) ga - $k \boldsymbol{a} \mathbf{j} \boldsymbol{a}$ ek het nie geeet nie I did not eat mêêtse a - kê a bela die water moet hoegenaamd nie kook nie the water should not boil whatsoever - sa nie meer nie no longer

se nie w. (negatiewe kop. ww. b. not (negative cop. v.) re- kgolê terwyl ons nie ver is nie while we are not far away $\boldsymbol{e}$ bê $\boldsymbol{e}$ - hy/sy was nie he/she was not

SEDIBA's entries are strong on coverage, they give examples from the imperative, future tense, subjunctive mood, indicative past tense, use with the auxiliary verb stem -ke, negation with the progressive, copulative descriptive, and even some guidance on the use of a copula in a past tense construction. The run-on layout, although indented, is less user friendly, e.g. compared to ONSD's entry for se which also gives grammatical and frequency information. Homonym indication by means of superscript numbers is recommended.

For $g a$ se the scope includes indicative past (3.1.3(1)(2)) for verbs in table 1 and dynamic copulatives (4.2.1.1.3(1)(2)) in table 3.

ONSD is the only dictionary treating $g a$ se in an excellent way distinguishing with homonym numbers between the copulative particle and the negative morpheme.

(5)

ga $^{1} \mathbf{s e}^{* * *}$ copulative particle $\mathbf{m}$ is/are not

- Batho bao ga se ba lapa la ka. Those people are not my family.

ga $^{2} \mathbf{s}^{2 * * *}$ negative morpheme $\operatorname{did}$ not (marks the negative form of past tense indica-

tive verbs) Ga se ke bone gore ke sefatanaga sa mang se se mo fološitšego mo

kgorwaneng. I did not see whose car dropped her off at the gate.

Consider also the suggestion for model entries for ga se by Prinsloo (2002: 36) in example (6):

(6)

ga se [cop. part. neg.] it is not, ga se phošo ya gago it is not your fault; he/she/it is not,

Satsope ga se morutiši, ke mongwaledi Satsope is not a teacher, she is a secretary;

they are not, dingaka ga se mahodu doctors are not thieves $\bullet$ ke $\bullet$ BM1.1; $\mathbf{m} \mathbf{m}$

...

se, ga $\sim$ ga se

In (6) a cross-reference marker " $\checkmark$ " informs the user that more information is available in the back matter of the dictionary. For the user who looked up se but actually need information about $g a$ se a reference entry is given at se with a cross-reference to ga se where a full treatment is given.

Provision of a text box at $g a s e^{1}$ in (5) for indicative, identifying, static copulatives (4.1.1.1, table 2) is recommended as learners or inexperienced users are often unfamiliar with the fact that no distinction is made in Sepedi for he is 
not, she is not, they are not and it is not and often result in incorrect utterances for, e.g. he/she is a teacher or they are teachers such as ${ }^{*} g a$ a morutiši or * ${ }_{g} a b a$ barutiši respectively.

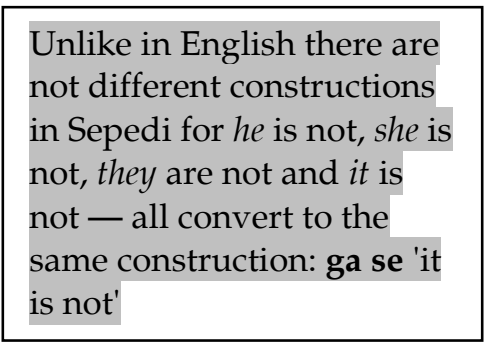

Treatment of $g a s e^{2}$ should include examples from the alternative negative strategies (3.1.3(1)(2), table 1) and could also be nicely complemented by a page footer containing the set of alternative concords used or a reference to the front, middle or back matter where all the alternative concords are presented together.

$1^{\text {st }}$ Person singular ka, $1^{\text {st }}$ Person plural ra, $2^{\text {nd }}$ Person singular wa, $2^{\text {nd }}$ Person plural la, Class: 1 a, 2 ba, 3 wa, 4 ya, 5 la, 6 a, 7 , sa, 8 tša, 9 ya, 10 tša, 14 bja, $15-18$ gwa

For $k a$ se the scope includes the future tense of the indicative (3.1.2), situative (3.2.2) and relative (3.3.2) in table 1 , and the future tense of all dynamic copulatives in the indicative (4.2.1.1.2), situative (4.2.1.2.2) and relative (4.2.1.3.2) in table 3.

As mentioned above, none of the dictionaries lemmatised $k a$ se. Consider an attempt towards a model entry for $k a$ se in (7).

(7)

ka $\mathbf{s e}^{1} * * *$ [ka se] (negative of the potential $\mathbf{k a}$ ) $\mathbf{c}$ can not, may not. Maripane a $\boldsymbol{k a}$ se kgônê. Maripane will not be able to nka se arabê potšišô yê I can not answer this question

$\mathbf{k a ~ s e}^{2} * * *$ [ka se] (negative of the future tense indicator tlo) $\mathbf{m}$ shall/will not $\boldsymbol{r e} \boldsymbol{k a} \boldsymbol{s e}$ boê we shall not come back gê ba ka se arabê if they will not answer yô a ka se ithutêgo ka mafolofolo he who will not study hard

Provision of a text box at $k a$ se is also recommended to inform the user about an important difference between the negative of the future in English and Sepedi. 


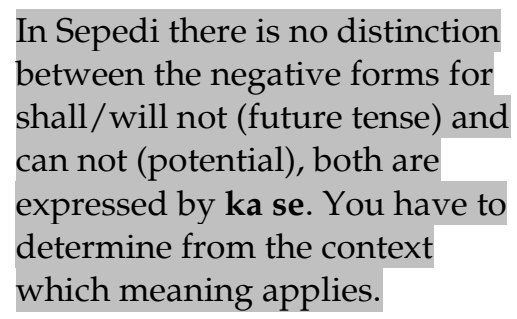

The examples in $k a \mathrm{se}^{1}$ indicate that the subject concord of class 1 is $a$ and that $k e+$ $k a$ changes to $n k a$ and in $k a s e^{2}$ illustrate and confirm the use of $k a$ se in the indicative, situative and relative. In this way the use of examples are not merely intended to confirm the existence of a word in the language but adds to the meaning information.

The text boxes at $g a$ se and $k a$ se appropriately illustrate the nature and purpose of text boxes in terms of Gouws and Prinsloo (2010: 501):

Text boxes are salient dictionary entries and as such they are used to place more than the default focus on a specific data item ... guidance in terms of sense, contrasting related words, restrictions on the range of application, register, pronunciation, et cetera. ... Where dictionaries have a text production function data could be included in a text box to emphasise the use or non-use of certain combinations and collocations as well as proscriptive guidance.

As far as the required information for the treatment of negative morphemes is concerned, one should not attempt to compile a one-size-fits-all set of information types. For paper dictionaries the lexicographer should keep in mind that the size of the dictionary, i.e. available physical space for an article is always a crucial consideration. Therefore, one cannot expect lengthy detailed articles for negative morphemes in small bilingual dictionaries such as POP, NEN, PUKU, PUKU'89, SEDIBA, etc. The challenge is maximum utilization of limited space and from the dictionaries discussed in reference to tables 6 to 9, ONSD comes closest to covering the most important information types in relatively short articles and in a user-friendly layout.

As a final suggestion for model entries consider also the front matter entry in figure 1: 


\section{Lemma in boldface}

Homonyms (unrelated meanings) superscript number

Frequency indicator

Phonetic transcription

Grammar guidance

\section{Translations}

Sepedi examples in bold italics

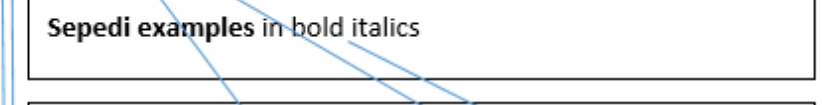

Translation of Sepedi examples in italics

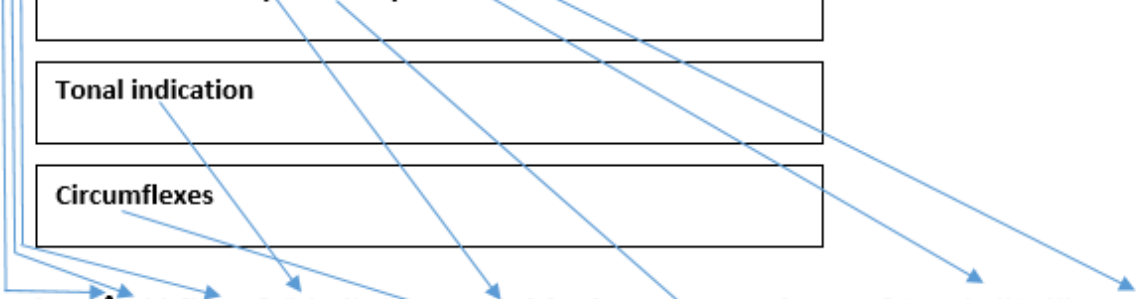

$\rightarrow \mathbf{k a ~ s} \mathbf{s}^{2 * * *}$ [ka se] (kà sè) (negative of the future tense indicator tlo) $\mathbf{a}$ shall/will not re ka se bồ we shall not come back gê ba ka se arabê if they will not answer yô a ka se ithutego ka mafolofolo he who will not study hard

Shaded / text box for additional guida
In Sepedi there is no distinction
between the negative forms for
shall/will not (future tense) and
can not (potential), both are
expressed by ka se. You have to
determine from the context which
meaning applies.

Figure 1: Suggestion for a model entry in the user's guide

Presenting figure 1 in the user's guide to the dictionary will guide the user to appreciation of the information types presented in the articles. 


\section{Conclusion}

Within the space limitations of an article it has been attempted to give an overview of negation in verbs and copulatives and the frequency of occurrence of negative morphemes in Sepedi. The focus was on the different negation strategies and the compilation of a list of lemma candidates to be treated in dictionaries for this language. A critical evaluation of a number of Sepedi dictionaries and suggestions for the scope and conventions for the treatment of negative morphemes were given. Model entries for dictionary articles for negative morphemes and user guidance in the front matter as well as comprehensive back matter entries were proposed.

\section{Acknowledgements}

This research is supported by the South African Centre for Digital Language Resources (SADiLaR).

\section{Endnote}

1. The Sepedi corpus is marked-up for part of speech which helped to determine frequency counts for the different negative morphemes. However, in order to verify these counts, manual calculations were also done on sections of the corpus to compensate for tagging errors or tags not refined enough to rule out false positives. The counts given in table 4 are therefore only intended to confirm that negative morphemes are frequently used in Sepedi.

\section{Bibliography}

\section{Dictionaries}

(GNSW) Ziervogel, D. and P.C. Mokgokong. 1975. Groot Noord-Sotho-woordeboek / Comprehensive Northern Sotho Dictionary / Pukuntšu ya Sesotho sa Leboa. Pretoria: J.L. van Schaik.

(KDS) Grobler, G.M.M. 1991. Die Kort Drietalige Sakwoordeboek. Pretoria: Ad Donker.

(NAAN) Kotzé, N.J. 1957. Noord-Sotho-Afrikaans, Afrikaans-Noord-Sotho woordelys. Johannesburg: Voorwaarts.

(NEN) Kriel, T.J. 1976. The New English-Northern Sotho Dictionary, English-Northern Sotho, Northern Sotho-English. Johannesburg: Educum Publishers.

(ONSD) De Schryver, G.-M. (Editor-in-chief). 2007. Oxford Bilingual School Dictionary: Northern Sotho and English. Cape Town: OUP Southern Africa.

(POP) Kriel, T.J., D.J. Prinsloo and B.P. Sathekge. 1997. Popular Northern Sotho Dictionary, Northern Sotho-English, English-Northern Sotho. Cape Town: Pharos.

(PTLH) Mojela, M.V. (Ed.). 2007. Pukuntšutlhaloši ya Sesotho sa Leboa. Pietermaritzburg: Nutrend.

(PUKU) Kriel, T.J. 1983. Pukuntšu Dictionary. Pretoria: J.L. van Schaik. 
(PUKU'89) Kriel, T.J. and E.B.Van Wyk. 1989. Pukuntšu woordeboek, Noord-Sotho-Afrikaans, Afrikaans-Noord-Sotho. Pretoria: J.L. van Schaik.

(SEDIBA) Lombard, D.P., R. Barnard and G.M.M Grobler. 1992. Sediba, Practical List of Words and Expressions in Northern Sotho, Northern Sotho-Afrikaans-English, English-Northern Sotho. Pretoria: Via Afrika.

(SEPD) Mojela, M.V., M.C. Mphahlele, M.P. Mogodi and M.R. Selokela. 2006. Sesotho sa Leboa / English Pukuntšu Dictionary. Cape Town: Phumelela.

(WANS) Gerber, H.H. 2000. Woordeboek Afrikaans-Noord-Sotho / Pukuntšu Seburu-Sesotho sa Leboa. Eldoraigne: Arbeidsprestasie BK.

\section{Other}

Bosch, Sonja and Gertrud Faaß. 2018. Options for a Lexicographic Treatment of Negation in Zulu. Kernerman, I. and S. Krek (Eds.). 2018. Proceedings of the LREC 2018 Workshop of GLOBALEX 2018, Lexicography \& WordNets, 8 May 2018, Miyazaki, Japan: 2-10. Miyazaki: Globalex.

Gouws, R.H. 1989. Leksikografie. Pretoria/Kaapstad: Academica.

Gouws, R.H. and D.J. Prinsloo. 2005. Principles and Practice of South African Lexicography. Stellenbosch: SUN PReSS.

Gouws, R.H. and D.J. Prinsloo. 2010. Thinking out of the Box — Perspectives on the Use of Lexicographic Text Boxes. Dykstra, A. and T. Schoonheim (Eds.). 2010. Proceedings of the XIV Euralex International Congress, Leeuwarden, 6-10 July 2010: 501-511. Leeuwarden: Fryske Akademy.

Lombard, D.P., E.B. van Wyk and P.C. Mokgokong. 1985. Introduction to the Grammar of Northern Sotho. Pretoria: J.L. van Schaik.

Louwrens, L.J. 1991. Aspects of Northern Sotho Grammar. Pretoria: Via Afrika.

Louwrens, L.J. 1994. Dictionary of Northern Sotho Grammatical Terms. Pretoria: Via Afrika.

Poulos, G. and L.J. Louwrens. 1994. A Linguistic Analysis of Northern Sotho. Pretoria: Via Afrika.

Prinsloo, D.J. 2002. The Lemmatization of Copulatives in Northern Sotho. Lexikos 12: 21-43.

Prinsloo, D.J. and R.H. Gouws. 1996. Formulating a New Dictionary Convention for the Lemmatization of Verbs in Northern Sotho. South African Journal of African Languages 16(3): 100-107. 
Appendix A: Verbal moods in Sepedi

\begin{tabular}{|c|c|c|}
\hline & Positive & Negative \\
\hline \multicolumn{3}{|c|}{ Indicative } \\
\hline Pres & $\begin{array}{l}\text { monna o bolela Sepedi } \\
\text { 'the man speaks Sepedi' }\end{array}$ & $\begin{array}{l}\text { monna ga a bolele Sepedi } \\
\text { 'the man does not speak Sepedi' }\end{array}$ \\
\hline Fut & $\begin{array}{l}\text { monna o tlo bolela Sepedi } \\
\text { 'the man will speak Sepedi' }\end{array}$ & $\begin{array}{l}\text { monna a ka se bolele Sepedi } \\
\text { 'the man will not speak Sepedi' }\end{array}$ \\
\hline Past & $\begin{array}{l}\text { monna o boletše Sepedi } \\
\text { 'the man spoke Sepedi' }\end{array}$ & $\begin{array}{l}\text { monna ga se a bolela Sepedi } \\
\text { 'the man did not speak Sepedi' }\end{array}$ \\
\hline \multicolumn{3}{|c|}{ Situative } \\
\hline Pres & $\begin{array}{l}\text { (ge) monna a bolela Sepedi } \\
\text { '(if) the man speaks Sepedi' }\end{array}$ & $\begin{array}{l}\text { (ge) monna a sa bolele Sepedi } \\
\text { '(if) the man does not speak Sepedi' }\end{array}$ \\
\hline Fut & $\begin{array}{l}\text { (ge) monna a tlo bolela Sepedi } \\
\text { '(if) the man will speak Sepedi' }\end{array}$ & $\begin{array}{l}\text { (ge) monna a ka se bolele Sepedi } \\
\text { '(if) the man will not speak Sepedi' }\end{array}$ \\
\hline Past & $\begin{array}{l}\text { (ge) monna a boletše Sepedi } \\
\text { '(if) the man spoke Sepedi' }\end{array}$ & $\begin{array}{l}\text { (ge) monna a sa bolela Sepedi } \\
\text { '(if) the man did not speak Sepedi' }\end{array}$ \\
\hline \multicolumn{3}{|c|}{ Relative } \\
\hline Pres & $\begin{array}{l}\text { monna yo a bolelago Sepedi } \\
\text { 'the man who speaks Sepedi' }\end{array}$ & $\begin{array}{l}\text { monna yo a sa bolelego Sepedi } \\
\text { 'the man who does not speak Sepedi' }\end{array}$ \\
\hline Fut & $\begin{array}{l}\text { monna yo a tlogo bolela Sepedi } \\
\text { 'the man who will speak Sepedi' }\end{array}$ & $\begin{array}{l}\text { monna yo a ka se bolelego Sepedi } \\
\text { 'the man who will not speak Sepedi' }\end{array}$ \\
\hline Past & $\begin{array}{l}\text { monna yo a boletšego Sepedi } \\
\text { 'the man who spoke Sepedi' }\end{array}$ & $\begin{array}{l}\text { monna yo a sa bolelago Sepedi } \\
\text { 'the man who did not speak Sepedi' }\end{array}$ \\
\hline \multicolumn{3}{|c|}{ Subjunctive } \\
\hline & $\begin{array}{l}\text { (gore) monna a bolele Sepedi } \\
\text { '(so that) the man must speak Sepedi' }\end{array}$ & $\begin{array}{l}\text { (gore) monna a se bolele Sepedi } \\
\text { '(so that) the man must not speak Sepedi' }\end{array}$ \\
\hline \multicolumn{3}{|c|}{ Habitual } \\
\hline & $\begin{array}{l}\text { monna a bolele Sepedi } \\
\text { 'the man (usually) speaks Sepedi' }\end{array}$ & $\begin{array}{l}\text { monna a se bolele Sepedi } \\
\text { 'the man (usually) does not speak Sepedi' }\end{array}$ \\
\hline \multicolumn{3}{|c|}{ Consecutive } \\
\hline & $\begin{array}{l}\text { monna a bolela Sepedi } \\
\text { '(then) the man spoke Sepedi' }\end{array}$ & $\begin{array}{l}\text { monna a se bolele Sepedi } \\
\text { '(then) the man did not speak Sepedi' }\end{array}$ \\
\hline \multicolumn{3}{|c|}{ Infinitive } \\
\hline & $\begin{array}{l}\text { go bolela Sepedi } \\
\text { 'to speak Sepedi' }\end{array}$ & $\begin{array}{l}\text { go se bolele Sepedi } \\
\text { 'not to speak Sepedi' }\end{array}$ \\
\hline \multicolumn{3}{|c|}{ Imperative } \\
\hline & $\begin{array}{l}\text { bolela Sepedi! } \\
\text { 'speak Sepedi!' }\end{array}$ & $\begin{array}{l}\text { se bolele Sepedi! } \\
\text { 'do not speak Sepedi!' }\end{array}$ \\
\hline
\end{tabular}


Appendix B: Static and dynamic copulatives in Sepedi

\begin{tabular}{|c|c|c|c|c|c|}
\hline STATIC COPULATIVE & Identifying & & & & \\
\hline & & 1 & Indicative & & \\
\hline Person: 1PS - 2PP & & & & & Classes 1-18 \\
\hline Pos & Neg & & & Pos & Neg \\
\hline \multirow[t]{2}{*}{ Ke moruti } & ga ke moruti & & 1 & monna ke moruti & monna ga se moruti \\
\hline & & 2 & Situative & & \\
\hline Person: 1PS - 2PP & & & & & Classes 1-18 \\
\hline Pos & Neg & & & Pos & Neg \\
\hline \multirow[t]{2}{*}{ (ge) ke le moruti } & (ge) ke se moruti & & 1 & (ge) monna e le moruti & (ge) monna e se moruti \\
\hline & & 3 & Relative & & \\
\hline Person: 1PS - 2PP & & & & & Classes 1-18 \\
\hline Pos & Neg & & & Pos & Neg \\
\hline yo ke lego moruti & yo ke sego moruti & & 1 & monna yo e lego moruti & monna yo e sego moruti \\
\hline \multirow[t]{2}{*}{ STATIC COPULATIVE } & Descriptive & & & & \\
\hline & & 1 & Indicative & & \\
\hline Person: 1PS - 2PP & & & & & Classes 1-18 \\
\hline Pos & Neg & & & Pos & Neg \\
\hline \multirow[t]{2}{*}{ Ke bohlale } & ga ke bohlale & & 1 & monna o bohlale & monna ga a bohlale \\
\hline & & 2 & Situative & & \\
\hline Person: 1PS - 2PP & & & & & Classes 1-18 \\
\hline Pos & Neg & & & Pos & Neg \\
\hline \multirow[t]{2}{*}{ (ge) ke le bohlale } & (ge) ke se bohlale & & 1 & (ge) monna a le bohlale & (ge) monna a sa se bohlale \\
\hline & & 3 & Relative & & \\
\hline Person: 1PS - 2PP & & & & & Classes 1-18 \\
\hline Pos & Neg & & & Pos & Neg \\
\hline yo ke lego bohlale & yo ke sego bohlale & & 1 & monna yo a lego bohlale & monna yo a sa sego bohlale \\
\hline \multirow[t]{2}{*}{ STATIC COPULATIVE } & Associative & & & & \\
\hline & & 1 & Indicative & & \\
\hline Person: 1PS - 2PP & & & & & Classes 1-18 \\
\hline Pos & Neg & & & Pos & Neg \\
\hline \multirow[t]{2}{*}{ Ke na le bohlale } & ga ke na (le) bohlale & & 1 & monna o na le bohlale & monna ga a na (le) bohlale \\
\hline & & 2 & Situative & & \\
\hline Person: 1PS - 2PP & & & & & Classes 1-18 \\
\hline Pos & Neg & & & Pos & Neg \\
\hline \multirow[t]{2}{*}{ (ge) ke na le bohlale } & (ge) ke se na (le) bohlale & & 1 & (ge) monna a na le bohlale & (ge) monna a se na (le) bohlale \\
\hline & & 3 & Relative & & \\
\hline Person: 1PS - 2PP & & & & & Classes 1-18 \\
\hline Pos & Neg & & & Pos & Neg \\
\hline yo ke nago le bohlale & yo ke se nago (le) bohlale & & 1 & monna yo a nago le bohlale & monna yo a se nago (le) bohlale \\
\hline
\end{tabular}


http://lexikos.journals.ac.za; https://doi.org/10.5788/30-1-1590

Lexicographic Treatment of Negation in Sepedi Paper Dictionaries

\begin{tabular}{|c|c|c|c|c|}
\hline DYNAMIC COPULATIVE & Identifying & & & \\
\hline & & 1 Indicative & & \\
\hline Person: 1PS - 2PP & & & & Classes 1-18 \\
\hline Pos & Neg & & Pos & Neg \\
\hline \multirow[t]{2}{*}{ Ke ba moruti } & ga ke be moruti & 1 & monna e ba moruti & monna ga e be moruti \\
\hline & & 2 Situative & & \\
\hline Person: 1PS - 2PP & & & & Classes 1-18 \\
\hline Pos & Neg & & Pos & Neg \\
\hline \multirow{2}{*}{ (ge) ke eba moruti } & (ge) ke sa be moruti & 1 & (ge) monna e eba moruti & (ge) monna e sa be moruti \\
\hline & & \begin{tabular}{l|l}
3 & Relative \\
\end{tabular} & & \\
\hline Person: 1PS - 2PP & & & & Classes 1-18 \\
\hline Pos & Neg & & Pos & Neg \\
\hline \multirow[t]{2}{*}{ yo ke bago moruti } & yo ke sa bego moruti & 1 & monna yo e bago moruti & monna yo e sa bego moruti \\
\hline & & \begin{tabular}{|l|l|}
4 & Subjunctive \\
\end{tabular} & & \\
\hline Person: 1PS - 2PP & & & & Classes 1-18 \\
\hline Pos & Neg & & Pos & Neg \\
\hline \multirow[t]{2}{*}{ (gore) ke be moruti } & (gore) ke se be moruti & 1 & (gore) monna e be moruti & (gore) monna e se be moruti \\
\hline & & \begin{tabular}{|l|l|}
5 & Habitual \\
\end{tabular} & & \\
\hline Person: 1PS - 2PP & & & & Classes 1-18 \\
\hline Pos & Neg & & Pos & Neg \\
\hline \multirow[t]{2}{*}{ ke be moruti } & ke se be moruti & 1 & monna e be moruti & monna e se be moruti \\
\hline & & \begin{tabular}{l|l|}
6 & Consecutive \\
\end{tabular} & & \\
\hline Person: 1PS - 2PP & & & & Classes 1-18 \\
\hline Pos & Neg & & Pos & Neg \\
\hline \multirow[t]{2}{*}{ ka ba moruti } & ka se be moruti & 1 & monna ya ba moruti & monna ya se be moruti \\
\hline & & 7 Infinitive & & \\
\hline Pos & Neg & & & \\
\hline \multirow[t]{2}{*}{ go ba moruti } & go se be moruti & & & \\
\hline & & 8 Imperative & & \\
\hline Pos & Neg & & & \\
\hline eba moruti! & se be moruti! & & & \\
\hline
\end{tabular}


http://lexikos.journals.ac.za; https://doi.org/10.5788/30-1-1590

344

D.J. Prinsloo

\begin{tabular}{|c|c|c|c|c|c|}
\hline DYNAMIC COPULATIVE & Descriptive & & & & \\
\hline & & 1 & Indicative & & \\
\hline Person: 1PS - 2PP & & & & & Classes 1-18 \\
\hline Pos & Neg & & & Pos & Neg \\
\hline \multirow[t]{2}{*}{ Ke ba bohlale } & ga ke be bohlale & & 1 & monna o ba bohlale & monna ga a be bohlale \\
\hline & & 2 & Situative & & \\
\hline Person: 1PS - 2PP & & & & & Classes 1-18 \\
\hline Pos & Neg & & & Pos & Neg \\
\hline \multirow[t]{2}{*}{ (ge) ke eba bohlale } & (ge) ke sa be bohlale & & 1 & (ge) monna a eba bohlale & (ge) monna a sa be bohlale \\
\hline & & 3 & Relative & & \\
\hline Person: 1PS - 2PP & & & & & Classes 1-18 \\
\hline Pos & Neg & & & Pos & Neg \\
\hline \multirow[t]{2}{*}{ yo ke bago bohlale } & yo ke sa bego bohlale & & 1 & monna yo a bago bohlale & monna yo a sa bego bohlale \\
\hline & & 4 & Subjunctive & & \\
\hline Person: 1PS - 2PP & & & & & Classes 1-18 \\
\hline Pos & Neg & & & Pos & Neg \\
\hline \multirow[t]{2}{*}{ (gore) ke be bohlale } & (gore) ke se be bohlale & & 1 & (gore) monna a be bohlale & (gore) monna a se be bohlale \\
\hline & & 5 & Habitual & & \\
\hline Person: 1PS - 2PP & & & & & Classes 1-18 \\
\hline Pos & Neg & & & Pos & Neg \\
\hline \multirow[t]{2}{*}{ ke be bohlale } & ke se be bohlale & & 1 & monna a be bohlale & monna a se be moruti \\
\hline & & 6 & Consecutive & & \\
\hline Person: 1PS - 2PP & & & & & Classes 1-18 \\
\hline Pos & Neg & & & Pos & Neg \\
\hline \multirow[t]{2}{*}{ ka ba bohlale } & ka se be bohlale & & 1 & monna a ba bohlale & monna a se be bohlale \\
\hline & & 7 & Infinitive & & \\
\hline Pos & Neg & & & & \\
\hline \multirow[t]{2}{*}{ go ba bohlale } & go se be bohlale & & & & \\
\hline & & 8 & Imperative & & \\
\hline Pos & Neg & & & & \\
\hline eba bohlale! & se be bohlale! & & & & \\
\hline
\end{tabular}


http://lexikos.journals.ac.za; https://doi.org/10.5788/30-1-1590

Lexicographic Treatment of Negation in Sepedi Paper Dictionaries

\begin{tabular}{|c|c|c|c|c|}
\hline DYNAMIC COPULATIVE & Associative & & & \\
\hline & & 1 Indicative & & \\
\hline Person: 1PS - 2PP & & & & Classes 1-18 \\
\hline Pos & Neg & & Pos & Neg \\
\hline \multirow[t]{2}{*}{ Ke ba le bohlale } & ga ke be le bohlale & 1 & monna o ba le bohlale & monna ga a be le bohlale \\
\hline & & \begin{tabular}{|l|l}
2 & Situative \\
\end{tabular} & & \\
\hline Person: 1PS - 2PP & & & & Classes 1-18 \\
\hline Pos & Neg & & Pos & Neg \\
\hline \multirow[t]{2}{*}{ (ge) ke eba le bohlale } & (ge) ke sa be le bohlale & 1 & (ge) monna a eba le bohlale & (ge) monna a sa be le bohlale \\
\hline & & \begin{tabular}{|l|l}
3 & Relative \\
\end{tabular} & & \\
\hline Person: 1PS - 2PP & & & & Classes 1-18 \\
\hline Pos & Neg & & Pos & Neg \\
\hline \multirow[t]{2}{*}{ yo ke bago le bohlale } & yo ke sa bego le bohlale & 1 & monna yo a bago le bohlale & monna yo a sa bego le bohlale \\
\hline & & \begin{tabular}{|l|l|}
4 & Subjunctive \\
\end{tabular} & & \\
\hline Person: 1PS - 2PP & & & & Classes 1-18 \\
\hline Pos & Neg & & Pos & Neg \\
\hline \multirow[t]{2}{*}{ (gore) ke be le bohlale } & (gore) ke se be le bohlale & 1 & (gore) monna a be le bohlale & (gore) monna a se be le bohlale \\
\hline & & \begin{tabular}{|l|l|}
5 & Habitual \\
\end{tabular} & & \\
\hline Person: 1PS - 2PP & & & & Classes 1-18 \\
\hline Pos & Neg & & Pos & Neg \\
\hline \multirow[t]{2}{*}{ ke be le bohlale } & ke se be le bohlale & 1 & monna a be le bohlale & monna a se be le moruti \\
\hline & & 6 Consecutive & & \\
\hline Person: 1PS - 2PP & & & & Classes 1-18 \\
\hline Pos & Neg & & Pos & Neg \\
\hline \multirow[t]{2}{*}{ ka ba le bohlale } & ka se be le bohlale & 1 & monna a ba le bohlale & monna a se be le bohlale \\
\hline & & \begin{tabular}{|l|l}
7 & Infinitive \\
\end{tabular} & & \\
\hline Pos & Neg & & & \\
\hline \multirow[t]{2}{*}{ go ba le bohlale } & go se be le bohlale & & & \\
\hline & & \begin{tabular}{|l|l|}
8 & Imperative \\
\end{tabular} & & \\
\hline Pos & Neg & & & \\
\hline eba le bohlale! & se be le bohlale! & & & \\
\hline
\end{tabular}

